\title{
GRASSLAND CHANGES AND PROGRESS IN TARANAKI SINCE 1951
}

G. R. MOSS, Farm Advisory Officer, Department of Agriculture, New Plymouth

Since our last conference held here in 1951 there has been a steady increase in production throughout Taranaki, but there have been, no spectacular changes in grassland farming.

Because some farmers have followed good management practices there has been a general overall improvement in farming efficiency. The story in Taranaki is little different from what has happened in other parts of New Zealand. From about 1950 to 1955 farmers were able to plough back a considerable amount of income into their properties. This is shown by the upsurge in livestock figures from 1955 to 1960 - the lag between expenditure and the effect was about three to four years. Since 1958 there has been much less money ploughed back into farms, especially on back country areas, and this is showing up in a slackening rate of increase in livestock numbers.

I doubt if there are many areas in the world with a more favourahle climate for grass production than the volcanic soils of Taranaki. The sunshine hours are high and the rainfall is regular. On coastal areas from Hawera to New Plymouth the average rainfall is between 45 and 60 in. Temperatures are mild with few frosts being recorded. The mean temperature recorded at New Plymouth for the coldest month, July, is $48.8^{\circ} \mathrm{F}$ and for the warmest month, February, $63{ }^{\circ}$.

Rainfall is well distributed. The following figures show the mean monthly rainfall in inches for New Plymouth over 67 years.

$$
\begin{aligned}
& \begin{array}{lllllllllllll}
\text { J } & & \text { F } & \text { M } & \text { A } & \text { M } & \text { J } & \text { J } & \text { A } & \text { S } & \text { O } & \text { N } & \text { D }
\end{array} \\
& \begin{array}{llllllllllll}
4.3 & 4.1 & 3.5 & 4.7 & 6.0 & 6.0 & 6.3 & 5.5 & 5.0 & 5.5 & 4.8 & 4.4
\end{array}
\end{aligned}
$$

The volcanic soils are free draining with a strong phosphatefixing property. They show an increasing potash deficiency. The only known minor element deficiencies worthy of mentioning are boron for brassica crops and copper for stock health on some of the peat soils.

On the volcanic plains at the foot of Mt. Egmont farming is predominantly dairying. Some fat lamb farming is sandwiched between these areas and the bush line in the high rainfall belt 
and between the central dairying areas and the store sheep hinterland. The steep rugged back country is devoted mainly to store sheep and cattle farming, with fat lamb farming on the increase in the valleys.

These back country soils are dominantly mudstone with flat volcanic tops. These soils respond to phosphorus and lime, but the economics of the liming is doubtful.

Grassland changes and progress in a district can best be measured by examining changes in stock numbers and productivity. Figures mean little by themselves, unless they can be compared with those for other areas to put them in perspective. Let's examine Taranaki's vital statistics and compare them with those of other North Island districts.

Since 1951 the number of milking cows has increased by 13 per cent from 258,000 to 292,000. Productivity measured in pounds of butterfat processed by dairy factories has increased by a similar figure. Many people will find such increases disappointing. In the light of new developments and the increased use of such techniques as herd testing and artificial breeding, progress, I think, has been disappointing. But the pattern of farming in any district is not static. In the last 12 years there has been a decrease in the number of dairy farmers milking 20 cows or more and a considerable increase in sheep flock numbers, with a significant increase in breeding ewes; Dairy herds have decreased by 6 per cent, sheep flocks carrying 500 sheep or more have increased by 34 per cent, sheep numbers have increased by 24 per cent, and breeding ewes by 41 per cent. The popular conception of Taranaki as solely a dairying area is changing. Today, over one-third of the farmers are sheep farmers.

The actual regional pattern of farming has changed little. Sheep farming is still confined to the back. country and dairying to the coastal and flatter areas. The trend away from dairying is mainly in the developing back country and this has been brought about by land development, aerial topdressing, and a change in our economic conditions.

The steady increase in breeding ewes is largely due to the swing away from milking cows; increased fertility has been brought about by more topdressing and by better farm management methods.

The percentage increase in dairy cow numbers is actually higher than in the other major dairying districts.

The decrease in herd numbers of 6 per cent is lower than in the other areas, except South Auckland. Therefore, in the national picture, Taranaki is more than holding its own in the dairying field. 
Sheep flocks and numbers of breeding ewes have increased at a faster rate in Northland and South Auckland, but Taranaki has more than kept abreast of the Wellington Land District. Taranaki has 14 per cent of the breeding-ewe population and 49 per cent of the total cattle population of the Wellington Land District, which has an occupied area 14 times that of Taranaki.

Over recent years the critical summer and winter feed shortages have declined on the farms where fertility has increased. On the warmer high fertility areas there is now active pasture growth during most of the winter months. Pasture species have played an important part in reducing winter feed shortages. Short-rotation ryegrass came and has fallen from favour, to be replaced on many farms by the non-certified weed grass, prairie grass. The decline in favour of short-rotation has been brought about by the lack of persistency caused by our management methods, and aggravated by Argentine stem weevil attacks.

The new certified cocksfoot was in great demand when first released. Unfortunately excess publicity for the new "Grasslands" cocksfoot slowed down the multiplication of this seed. In the earlier stages much pedigree seed was sown by Taranaki dairy farmers instead of seed producers.

The new hybrid ryegrass promises to be a valuable and welcome addition to our dairy pastures. There is a need for an early spring, strong summer growing species that will stand up to establishment troubles and. a high stocking rate. There are indications that this grass will help control excess clover growth during establishment and will help smother weeds.

Clovers grow most vigorously on our volcanic soils if well topdressed with adequate phosphorus and potash. Clover dominance is a major problem, especially during pasture establishment.

Prairie grass has played a remarkable part on our lighter, warmer, high fertility areas. It's especially suited to coastal town milk production, but its variable nature, its slow establishment, and its lack of persistency under very heavy stocking set the plant breeder a rewarding task.

Perennial ryegrass comes up for much criticism but as yet there is no satisfactory substitute. It is still the key grass for Taranaki's back country and dairy farms.

Because of the type of country, the problems, and the low fertility, new pasture species have played little part in our back country over the last 12 years. Back country problems, are associ-. ated with lack of farming pressure. Weed control with stock, subdivision, and aerial topdressing are key factors in good pasture management. Credit must be given to the bulldozer and the Land Rover in opening up access. 
There have been no spectacular changes in pasture management on dairy farms over recent years, but there has been a progressive change throughout the district, especially in certain areas, such as South Taranaki. The main changes worthy of note have been the increased use of fertilisers, the acceptance of autumn-saved pasture, better grazing and wintering systems, better subdivision, and universal acceptance of farm access races. The mains-operated electric fence has given a means of cheap subdivision.

It is of interest to note that five or six years ago autumn-saved pasture was closed up during March-April. Now on many farms the period has tended to become later-May, or even June, because of increased fertility and better winter growing pastures.

An increasing number of farmers spray pastures before grazing to overcome bloat in cows. Unfortunately, there are still many farmers who seek an easy way out of this problem and other metabolic diseases by buying "shot-gun" minor-element mixtures. Spraying, when carried out correctly, appears to be the only satisfactory practical technique for large-scale bloat control.

Harrowing as a normal farm practice is on the decrease. Under high stocking rates increased worm activity lessens the need for the grassland harrows.

Although more autumn-saved pasture is used now than ever before, more hay and silage is being made. This is at the expense of summer production. There is less reason for saving supplementary feed, but because of the conservative nature of farmers, grass is not being fully utilised and much production is being wasted. Last year 20,000 acres more hay and silage were made than 12 years ago.

Over recent years there have been changes in silage making. The pit, the stack, and the silo were largely replaced by the wedge owing to the use of the buckrake. The trend today is back to the pit, thanks to the development and acceptance of the forage harvester. The forage harvester permits the making of a better quality article, but much silage is still wasted owing to the lack of consolidation and sealing or roofing. Self-fed silage is being accepted very slowly. In future, self feeding of hay and silage off a central race should become popular. The ultimate aim is all-grass farming with little or no supplements.

From the way farmers readily accepted the forage harvester, it would appear they are more ready to accept a new machine than a new farming technique; perhaps it is because of good salesmanship and high pressure advertising..

The quality of grass seeds sold in Taranaki today is particularly high. A cheap-seed trade is almost non-existent. Farmers sow 
high quality Certified, seeds, thanks to the purchasing policies of the local produce firms.

Cropping has increased by 17 per cent, bringing the acreage of fodder crops sown last year up to 18,000 acres. Cropping is almost solely confined to the brassica fodder crops. Most cropping is carried out as part of a development programme. It's only a matter of time until cropping acreages decline. Mr B. A. J. Smith of Hawera reports a definite trend in South Taranaki to all-grass farming as a result of increased fertility, insect attacks on new grass, and the relatively poor production from newly grassed areas during the first three years.

Since 1951 there has been a 1 per cent decrease in grassed areas. This is not very significant, as a swing towards forestry has accounted for much of this acreage. The high cost of bush-felling today makes large blocks of forest uneconomic for development, unless valuable timber is available to meet costs. Each year many small areas of bush are being cut and burnt on the smaller farms.

Loans under the Marginal Lands Act have assisted considerably in the development of the back-country. Since 1951 over $£ 206,000$ has been advanced to local farmers for clearing scrub, grassing, fencing and manuring.

Because some of the top-producing dairy. farms in Taranaki are getting high production off old pasture swards, many farmers favour pasture improvement by other means than the plough. Heavy topdressing and intensive stocking on old swards can completely change a pasture. In the case of extremes, a dominant bracken fern-browntop-fog sward can be changed to a ryegrasswhite clover-prairie grass sward. New species are commonly introduced by seeding after a pugging and feeding-out period during the winter. Results in some cases are very spectacular. The advantage of such a system is its simplicity and low cost. Farmers argue in its favour that there is little in the way of clover dominance and stem weevil trouble, and you leave the topsoil @here you want it.

A pasture renewal programme in which the orthodox method is used is faster, but the risks and the costs are greater. A combination of the two methods appears desirable. This is the system practised by the majority of farmers who are endeavouring to increase production rapidly. Indications are that the new hybrid ryegrass will assist in overcoming our serious establishment problems.

The once fashionable technique referred to as undersowing or underdrilling has come and almost gone. It has been abandoned largely because of disappointing results from drilling high-produc- 
Over recent years contract bulk handling of fertiliser has increased considerably. Bulk spreading commenced in 1952. Last year 32,000 tons were applied by bulk contractors. This figure represents 29 per cent of the fertiliser applied.

Aerial topdressing has played the major part in the increase in stock numbers of the back country. Full credit must be given to the firms and the pilots who carry out this hazardous job. Some of this topdressing is being wasted because of insufficient fencing or lack of stock to cope with the extra feed grown. Some farmers borrow money for topdressing, waste it, and continue to pay interest on a lost asset because they failed to capitalise on the extra feed.

DDT manures have played an important part in the increase in production over recent years. In the peak year $(1960 / 61)$ over 23,000 tons of DDT manure were manufactured in New Plymouth.

Much fertiliser has been wasted as a result of the destructive grass feeding habits of three insect pests, the grass grub, the porina, and the Argentine stem weevil. Unless satisfactory methods of control, preferably biological control, can be found, these insect pests will continue to cost Taranaki very large sums.

Goats and opossums cause deforestation in a number of back country areas, which leads to slipping and flooding of farm lands. Rabbits and goats do a limited amount of damage by grazing pastures, and opossums damage numerous crops handy to pockets of native bush.

Because of our soils and climate, weeds are a 'major problem. The only satisfactory method'of controlling the majority of weeds (gorse, blackberry, manuka, inkweed, tall fescue, and other similar weeds) is by more intensive farming. Chemical weedkillers have come into their own over recent years, but they are costly and remove only the weed and not the symptom causing its growth. Extension officers in Taranaki consider farmers give too much credit to such methods of weed control and they feel that more emphasis should be placed on better management methods. In future new chemical weedkillers may play an increasingly important part in this district, especially in the control of gorse and manuka in the back country.

To the extension worker, with his knowledge of the potential of Taranaki (and of what some farmers can do in the light of present agricultural developments) progress in the past 12 years, especially in dairy production, has been disappointing. There is a big potential in our backcountry, but problems there are not as easy to overcome as on dairy farms. Some are national and political problems. When you consider that some of our counties 
have over 50 per cent of their areas still in bush and scrub, the farming potential of the back country can be clearly seen. But the high cost of development, the shortage of labour, the difficult topography, and the lack of access roading make large-scale development a State project under our present cost structure. Today schooling, roading, and community facilities are more important than they have ever been in encouraging back country development. Our back country needs men with vision, experience and working capital. Unfortunately the Land Aggregation Act does not encourage such men and is a serious limiting factor in holding back much of our deteriorating areas.

In lnglewood County a recent survey of a random sample of 10 per cent of all dairy farms showed that the average farm was running less than one milking cow to two acres and the production per grassed acre was only $162 \mathrm{lb}$ of butterfat. Waimate West County in South Taranaki has the highest dairy cow population per acre in New Zealand. If we convert Waimate West stock figures to ewe equivalents, we find that the carrying capacity of this county is higher than that of Kairanga County in Manawatu, yet Waimate West is milking only $3 / 5$ cow to the acre. Extension officers and progressive farmers in South Taranaki claim a potential for the area of a cow and a quarter to the acre. On the Waimate West Demonstration Farm at Manaia, a small herd being run at $1 \frac{1}{2}$ milking cows per acre has produced almost $500 \mathrm{lb}$ of butterfat per cow per acre on an area receiving a limited amount of topdressing.

Why has progress been so disappointing over this period? One can only guess. I believe progress has been disappointing for some of the following reasons: lack of incentives, because of economic conditions; lack of skilled labour, or any sort of labour; and lack of working capital. The high price of land has meant greater indebtedness and less working capital, especially to the man starting out. The Inglewood survey already mentioned showed the -average farm value in Inglewood County to be $£ 15,000$ and the net annual income $£ 1,400$.

One of the factors limiting production is the farmer himself, because usually he lacks a basic scientific farm training. This is not the farmer's fault; he is a conscientious, hard-working, good citizen. There is no practical training in scientific agriculture worth mentioning available to the masses. I would go so far as to say much money spent on research is being wasted because new developments are not, and cannot be put into practice because of a lack of agricultural training. But agricultural education is not a simple formula for increasing production. It is a foundation stone 
for future generations to build on. Partial methods,' such as increased youth education through Young Farmers' Clubs, more extension workers, and farm improvement clubs would be a sound investment.

Field experience of many dairy farmers has shown that spectacular production increases can be obtained by heavy and regular applications of the correct manures. Though the tonnage of fertiliser applied in Taranaki has nearly doubled since 1950/51, dairy production has shown an alarming lag because farmers have failed to appreciate the value of the extra feed grown. Poor utilisation of pasture is the greatest factor limiting production today.

Extension officers agree that Taranaki has a big production potential. I, for one, believe that 100 per cent increase in production is feasible in many areas, if we use our present knowledge effectively, without any new developments from research. The biggest percentage of farmers, perhaps 85 per cent, need carry 'out only a few basic principles to increase production. They need more fertiliser and more stock.

The remaining 15 per cent are the better farmers, who now require the services of field research to assist them with immediate problems. This group is an important group, because it is the one that sets the standards. The problem for the extension officer, with his limited staff and fully occupied time, is which group to help first. He knows full well that the greatest returns come from the mass, but the greatest noise comes from the minority.

In Taranaki the recipe for rapid progress in farm productivity is simple. Soil fertility must be raised by adequate and correct topdressing, insect pests must be controlled, and pastures must be skilfully managed and fully utilised by adequate numbers of high producing, healthy stock.

\section{Acknowledgement}

I wish to acknowledge advice and suggestions from the Taranaki Extension Officers.

\section{DISCUSSION}

Q. Do you recommend soil testing for determining the use of the right type of fertiliser?

A. Obtain the opinion of the local Farm Advisory Officer. He may be able to offer advice without soil testing based on his intimate knowledge of the land.

Q. Could Mr Moss give any indication whether-or not the sheep increases outlined occurred mainly on sheep farms alone, or does it include land formerly used for dairying.

A. Many small back country dairy farmers have, through experiencing better economic climate changed to sheep farming. 